\title{
Leadership Style, Compensation And Its Effect On Employee Performance (PT. SSBP Case)
}

\author{
Elly Alfrida1) \\ Elly.alfarida@ubd.ac.id \\ Petrus T. Resi') \\ Petrus.resi@ubd.ac.id \\ Sabam Simbolon ${ }^{3}$ \\ sabam.simbolon@ubd.ac.id \\ 1) 2) 3) Universitas Buddhi Dharma, Indonesia, Banten
}

\begin{abstract}
This research is aimed at understanding the relationship of leadership style and compensation on employee performance at PT SSBP considering that the two independent variables are the main factors that determines the success of a company as general as well as PT SSBP. The research obtained data from 144 respondents out of 210 total employees. A questionnaire was prepared to catch their perception on leadership style and compensation and how they affect their performance in the company they work with. From the data obtained and the analysis result shows that the relationship and the contribution of leadership style and compensation on the performance of employees is strong and significant, either partially or simultaneously. Therefore as managerial instruments, leadership style and compensation are extremely important factors to be considered and continuously updated in order to keep and maintain employees motivation that in turn will boost their performance,
\end{abstract}

Keywords: Leadership style, compensation, performance. 


\section{Preliminary}

Leaders and compensation are part of management that are very directly experienced by employees of an organization. Therefore, the proper application of these two managerial aspects will greatly impact employees, including the efforts of employees in achieving organizational goals. Al-Malki and Juan (2018) conducted a "literature review" regarding the influence of leadership style on performance, suggesting that leadership style has a positive impact (efficiency) by influencing the performance of organizational members and negatively (role stressors) such as ambiguity and role conflict which are the main sources of disruption. - job satisfaction ( $p, 40)$. Uwiyeze and Muryungi (2017) in other parts of the world try to see the link between compensation and performance. They find that the compensation in its complete package contributes greatly to employee performance, in addition to playing a role in retaining quality employees (p. 160). Ibojo and Osabi (2014) demonstrate that good compensation management will also improve employee performance and retain quality employees (p.108).

The increasingly competitive world of business presumes that companies must maintain and improve their performance continuously. Among other things is to implement appropriate leadership and compensation policies. Therefore, examining the leadership style and compensation policy will greatly assist decision makers in order to improve organizational performance.

Employee performance through the achievement of organizational / company goals does not only depend on work systems, work methods, capital or technology, but also depends on the role of human resources who carry out the work. Human resources are important in an organization because they function to manage various resources owned by the company. So every company always strives to improve employee performance in the hope of achieving its goals(Andy \& Sutrisna, 2018).

The application of the appropriate leadership style and the right compensation policy will greatly encourage employee participation (human resources) in achieving company goals. Leaders may have certain views about a good leadership style. Likewise with certain compensation policies that are applied. However, it would be very good if employees' perceptions of these two important elements are also very important for the leadership of a company to know. Because the view that organization is a 'melting pot' of different human beings has begun to be abandoned. Respecting diversity as a potential source of innovation and creativity presupposes that leaders must adapt to what their employees perceive as the most valuable resource in the organizations they lead. This will feel increasingly important in today's era where information technology opens up all aspects of life including the policies of competitors, which are very easy for employees to know and understand. Thus ignoring the perceptions and views of employees can make it easier for other companies to hijack one company's employees. And this is becoming more and more common. 
PT SSBP as a relatively new steel (pipe) manufacturing company (since 2007) has a high 'switching cost' because it invests in very specific machinery which presupposes the sustainability of its suction over a long period of time. Therefore retaining the best employees is a must. Therefore understanding employees is a necessity. Thus the questions in this research that will be tried to be answered are:

1. How is the relationship and the partial contribution of leadership style to employee performance at PT SSBP?

2. How is the relationship and compensation contribution to employee performance partially at PT SSBP?

3. How is the relationship and contribution of leadership style and compensation to employee performance simultaneously at PT SSBP?

The model of this research can be visualized as shown below.

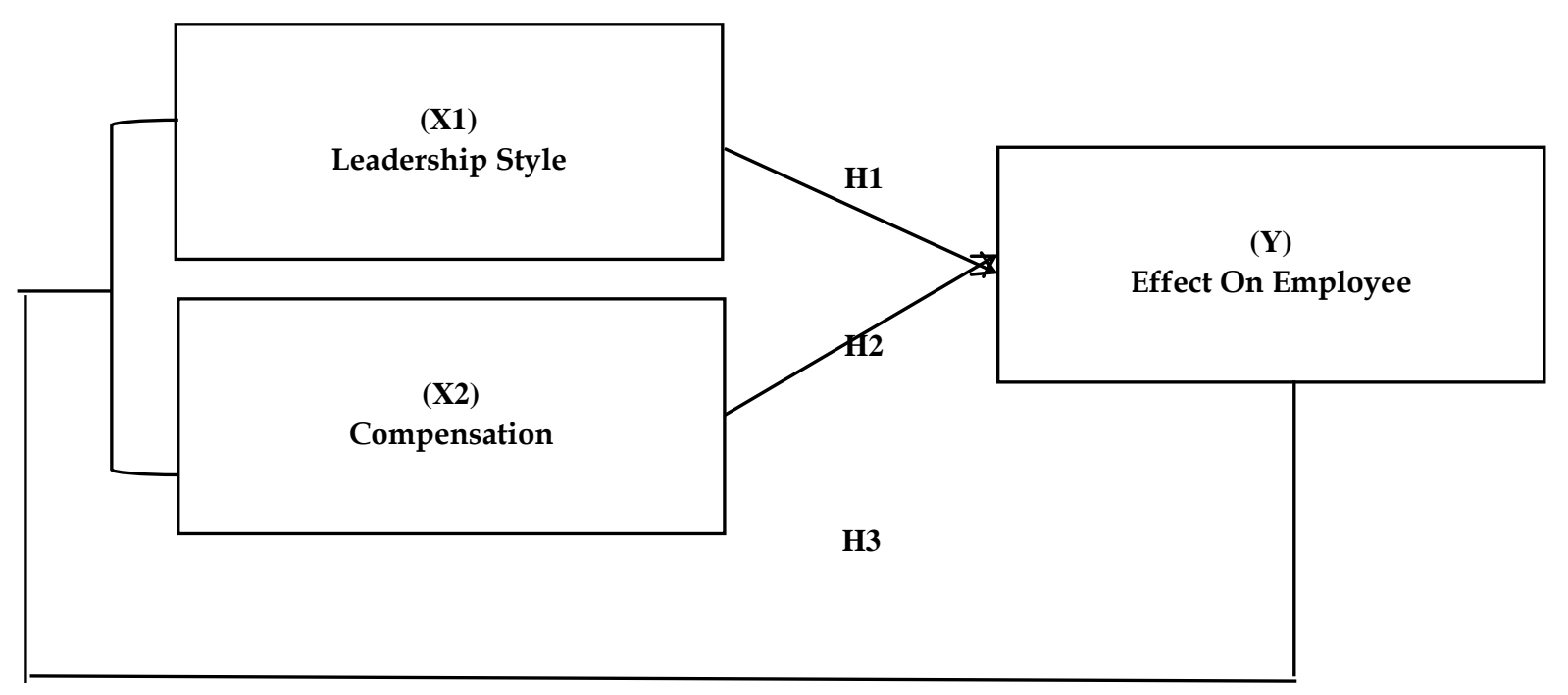

\section{Literature review}

Leadership is the affair of all modern humans, leadership is a process not a position, leadership is a complex phenomenon that includes leaders, followers and situations. This is reflected in the development of the investigation of leadership itself. Chronplogically, leadership begins by investigating whether certain characteristics of humans make a person a leader or not whether it is a physical or psychological characteristic. The focus then shifts to whether certain behaviors make a person an effective leader or not. The next investigation is focused on situations where the emphasis is on the compatibility between followers and leaders. (Hughes, Ginnett, and Curphy, 2006: 6).

The investigation of these three things is intended so that whether traits, behaviors, or situations can make the meaning of leadership itself operational in an organization. Sutikno $(2014,16)$ argues that leadership is "... influencing the people they 
lead, so they want to do as expected ... by others who lead them". Or as quoted by Cepi Priatna in Katz and Kahn (Priatna, 2015, 30) leadership is: “.... the gradual increase in influence goes beyond mechanical adherence to the organization's routine directions ". In addition, Shafie, Baghersalimi and Bagher also suggest the notion of leadership as: 'an ability to influence attitudes, beliefs, and abilities of employees to achieve organizational goals "(Shafie, Baghersalimi and Bagher (2013: 22)Kepemimpinan dalam tindakan dinyatakan oleh seorang pemimpin di dalam gaya kepemimpinan yakni: "set of behavior patterns that frequently occurs' which lasts as long as the organization operates which allows leaders to work with their followers which in turn has an impact on the morale of their followers and in the end the morale of their followers will affect organizational performance (Shirzad \& Zanganeh, 2011).

The leadership style can show the extent of the leader's authority and power in decision-making ranging from autocratic, democratic to participatory styles. The autocratic style is more characterized by the "I tell" philosophy in which the leader will tell his subordinates what to do. This is important if the organization faces crises or "urgent" matters that require immediate responses. Democratic power is characterized by the philosophy of "I share", that is, decisions are taken in a team where each member provides the same input. Meanwhile, the participatory style is characterized by the involvement of all team members starting from identifying problems and objectives as well as processes and strategies to achieve these goals. This latter style presupposes the leader to function more as a facilitator (Iqbal $\mathrm{N}$ et al, 2015).

Which leadership style is used by a leader is largely determined by the situation or "contingency" (Peretomode, 2012) faced by leaders in the organizations they lead. Situations can involve the maturity of followers / subordinates (willingness and ability). Or it could be related to task structures, namely jobs with standard work processes and procedures or specific jobs that require employee creativity in carrying out their duties. Another situation could involve the relationship between the leader and his subordinates.

Compensation is a need that is very motivating and ultimately spurs employee performance. For this reason, providing adequate compensation in a fair and adequate sense is very important. In other words, good compensation is very strategic for the organization. Good compensation not only answers the needs of employees but is also another form of organizational recognition and appreciation to their employees.

Compensation is "the return of he service rendered" which is part of a work relationship. And this has a huge influence on recruitment, motivation, productivity and employee 'turnover' (Uwizeye and Muryungi, 2017: 161). Good compensation for employees not only benefits employees but also reflects the company's value. Compensation includes salaries / wages, incentives, and allowances. Salary / wages are a function of qualifications and time, incentives are a function of performance, while allowances are a consideration of welfare and are usually determined by regulation. 
Thus applying the right leadership style and appropriate compensation is expected to improve the performance of human resources in an organization / company. Mangkunegara $(2014,9)$ states performance is "work performance or work results ... in accordance with responsibilities". Bangun (2014: 231) states that performance is "the result achieved by a person based on job requirements". Previous studies have shown that the application of a good and proper leadership style and compensation can bring positive contributions to employees and the organization / company. Research is also carried out in various types of organizations and shows positive impacts. Habbeb and Ibrahim (2017) conducted a study at a university that found that the leadership style applied had a positive impact on employees such as increasing morale, intrinsic satisfaction and motivation which would certainly have an impact on their performance. Veliu. Manxhari and Demiri (2017) explored employees' perceptions of leadership styles and found, among other things, that democratic, autocratic and transformational leadership styles had a positive impact on employee performance, while carimatic, bureaucratic and laissez-faire leadership styles had a negative impact on employee performance even though they were not significant. Ollan and Rousel (2017) in their study of a public / government organization also found that the right leadership style will greatly determine employee performance. They found that affiliative and authoritative leadership must be applied simultaneously to improve employee performance. Basit, Sebastian and Hassan (2017) in their research on a private organization also found that the most positive democratic leadership style perceived by employees in improving their performance was followed by laissez-faire and autocratic styles.

Research on the impact of compensation also shows a good influence on performance as shown by Abadi and Renwarin (2017) that appropriate compensation has a significant impact on performance. Even Priyono, Suci and Chandra (2015) found that compensation in the form of incentives has a very strong relationship with employee performance so that it has a strong influence.

\section{Methodology}

This research is a descriptive study that aims to explore and clarify social phenomena or realities by describing the variables related to these phenomena, among others, by connecting one variable to another. In this study, descriptive analysis was used to determine how the relationship and influence of leadership style, compensation and performance at PT. Sinar Surya Bajaprofilindo.

PT.Sinar Surya Bajaprofilindo is engaged in manufacturing pipes that are ISO 9001: 2008 certified for quality management system standards and accredited by SNI for ERW Tube and C-Channel products. Located on Jl. Raya Serang KM 14,5 No. 31, Cikupa, Tangerang 15710 Banten - Indonesia. The population of this study were all PT.SSB employees as many as 226 people. From this population, the research sample was 
determined using the SLOVIN formula quoted from the book V. Wiratna Sujarweni $(2015,82)$. In this study the standard error was $5 \%$.

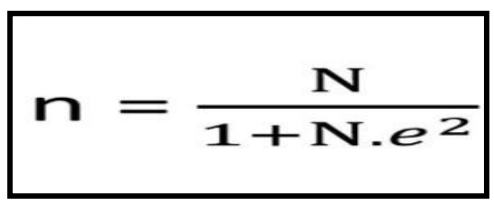

$\mathrm{n}=$ Number of Samples

$\mathrm{N}=$ Total Population

$\mathrm{e}=$ the error tolerance limit / desired error rate

By entering the data into the formula above, it was found that $n=144$ people were sampled in this study. The technique for determining the sample is the snow ball technique. They were distributed questionnaires that had been prepared to find out their perceptions of the leadership style of their leaders, their perceptions of the compensation provided by the company for them, and their perceptions of their performance during their work at PT SSB.

Data collected through 144 respondents were then tabulated and grouped according to research variables then processed using the SPSS version 21.0 package for further analysis and interpretation to answer this research problem.

\section{Results and Discussion}

The research was conducted at PT. Sinar Surya Bajaprofilindo (PT. SSB) with 144 employees as respondents. Respondent profiles according to gender were as many as 130 men $(90.3 \%)$ and women as many as 14 people $(9.7 \%)$. Most of the respondents aged between 21 and 40 years, about $87 \%$. Almost all of the respondents' education level is between SMA and S1 (99\%). And the working period of the majority of respondents is over 5 years $(51.4 \%)$ and between 1 and 5 years of $38.2 \%$.

The data were collected using a questionnaire as a research instrument. The instrument used is valid and reliable (reliable). Said to be valid because in accordance with the validity test carried out on all items (items) of the instrument for the three variables, the value of $\mathrm{T}$ count is greater than the Ttable for all items. The instrument is also said to be reliable in measuring employee perceptions of the three variables of this study. This is known through the reliability test where the Alpha for all three variables is above 0.7. Thus, the data obtained is also valid and reliable. The following is a graph that shows the data collected using the instrument / questionnaire is normally distributed. 


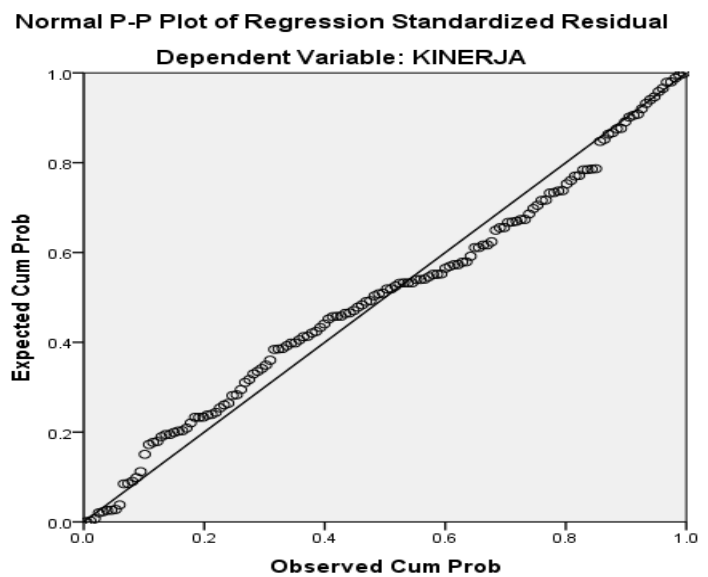

Besides, the multicollinearity test results also show no correlation between the independent variables. This can be seen in the following table. Namely, the tolerance value $>0.1$ and $\mathrm{VIF}<10$.

\section{Multikolinearitas Tables}

\begin{tabular}{|c|c|c|c|}
\hline \multicolumn{4}{|c|}{ Coefficients $^{a}$} \\
\hline \multirow{2}{*}{\multicolumn{2}{|c|}{ Model }} & \multicolumn{2}{|c|}{ Collinearity Statistics } \\
\hline & & Tolerance & VIF \\
\hline \multirow{2}{*}{1} & KEPEMIMPINAN & .908 & 1.101 \\
\hline & KOMPENSASI & .908 & 1.101 \\
\hline
\end{tabular}

a. Dependent Variable: Effect On Employee Sumber SPSS versi 21.0

The heteroscedasticity test also shows that the residual variants are not the same in all observations. This can be seen in the distribution of data in the following graph, where the dots do not form a clear pattern and the data distribution points spread above and below zero so that it can be concluded that heteroscedasticity does not occur.

Scatterplot

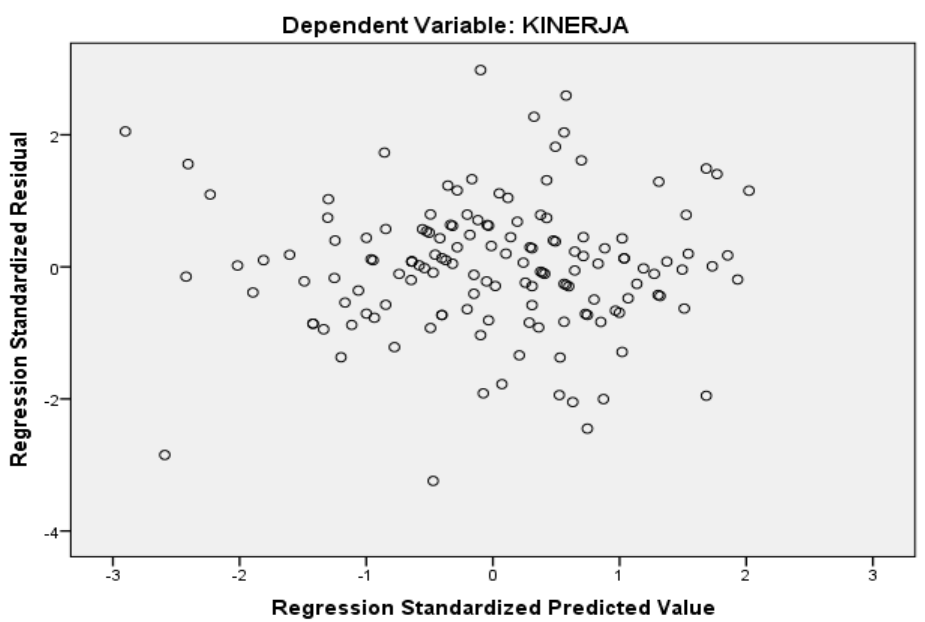




\section{Leadership Style and Performance Tables}

\begin{tabular}{|l|r|r|r|r|}
\hline Model & $r$ & $r$ Square & $\begin{array}{c}\text { Adjusted R } \\
\text { Square }\end{array}$ & $\begin{array}{c}\text { Std. Error of the } \\
\text { Estimate }\end{array}$ \\
\hline 1 & $.637^{\mathrm{a}}$ & .406 & .401 & 3.798 \\
\hline
\end{tabular}

a. Predictors: (Constant), Leadership

b. Dependent Variable: Effect On Employee

Sumber SPSS versi 21.0

Table 4.2. Above, it can be seen that the relationship between leadership style and performance is strong as seen from the correlation coefficient $r$ of 0.637 (63.7\%). Likewise, employee performance is determined by the leadership style of the determinant coefficient (r square) of 0.406 (40.6\%).

\section{Compensation and Performance Tables}

\begin{tabular}{|l|r|r|r|c|}
\hline Model & $r$ & $r$ Square & $\begin{array}{c}\text { Adjusted R } \\
\text { Square }\end{array}$ & $\begin{array}{c}\text { Std. Error of the } \\
\text { Estimate }\end{array}$ \\
\hline 1 & $.490^{\mathrm{a}}$ & .240 & .234 & 4.295 \\
\hline
\end{tabular}
a. Predictors: (Constant), Leadership
b. Dependent Variable: Effect On Employee
Sumber SPSS versi 21.0

Likewise with compensation. From table 4.3. It can be seen that the relationship between compensation and performance is moderate as seen from the correlation coefficient of $0.480(49 \%)$ while the determinant coefficient is $0.24(24 \%)$ which shows the contribution of compensation to employee performance.

\section{Table Multiple Correlation}

\begin{tabular}{|l|r|r|r|r|}
\hline $\begin{array}{l}\text { Mod } \\
\mathrm{el}\end{array}$ & $\mathrm{R}$ & $\mathrm{R}$ Square & $\begin{array}{c}\text { Adjusted R } \\
\text { Square }\end{array}$ & $\begin{array}{c}\text { Std. Error of } \\
\text { the Estimate }\end{array}$ \\
\hline 1 & $.709^{\mathrm{a}}$ & .502 & .495 & 3.487 \\
\hline
\end{tabular}
a. Predictors: (Constant), Compensation, Leadership
b. Dependent Variable: Effect On Employee
Sumber SPSS versi 21.0

Furthermore, together leadership style and compensation have a strong relationship with performance seen in the multiple correlation coefficient (R) of 0.709 or $70.9 \%$. While the determinant coefficient is equal to Rsquared 0.502 or $50.2 \%$. The relationship and influence between leadership style and compensation with performance is 
significant as seen in the following ANOVA table where the sig is 0.00 less than the standard error of $0.05(0.00<0.05)$

Table ANOVA

\begin{tabular}{|l|l|l|l|l|l|l|}
\hline Model & $\begin{array}{l}\text { Sum } \\
\text { Squares }\end{array}$ & of & df & $\begin{array}{l}\text { Mean } \\
\text { Square }\end{array}$ & F & Sig. \\
\hline \multirow{2}{*}{$\begin{array}{l}\text { Regression } \\
1\end{array} \quad \begin{array}{l}\text { Residual } \\
\text { Total }\end{array}$} & 17140.938 & 2 & 865.469 & 71.171 & $.000^{\mathrm{b}}$ \\
& 3445.556 & 141 & 12.160 & & \\
\hline
\end{tabular}

a. Dependent Variable: Effect On Employee

b. Predictors: (Constant), Compensation, Leadership Sumber SPSS versi 21.0

\section{Conclusions and Implications}

From the results of the statistical analysis presented above, it can be concluded that the relationship between leadership style and compensation to employee performance is positive and significant, both partially and simultaneously. Likewise, the contribution between leadership style and compensation for performance is also large. Thus for PT SSBP these two factors need to be observed and become an important factor in improving the performance of its employees.

\section{Referensi}

ABbadi, Ferryal dan Renwarin, Joseph MJ,', Analysis on the Influence of Compensation and Leadership on Job Satisfaction and Its Effect on JobPerformance'. Advances in Intelligent Systems Research, volume 131 International Conference of Organizational Innovation (ICOI 2017)

Andy, \& Sutrisna. (2018). Analisis Pengaruh Kedisiplinan Kerja , Prestasi Kerja Dan Semangat Kerja Terhadap Pemberian Bonus Karyawan Pada PT . Reka Sukses Adipratama Understanding the Relationship between Affective Commitment and Continuity Commins at Buddhi College Tangerang. Primanomics : Jurnal Ekonomi Dan Bisnis - Vol. 16. No. 1 (2018), 1, 18-33.

Al-Snsi. Abdullah M, Rahardjo Kusdi dan Prasetya, Arik,'Analysis Impact Of Leadership Style And Pay Fairness On Job Satisfaction And Organizational Commitment'. IOSR Journal of Business and Management (IOSR-JBM), Volume 17, Issue 3.Ver. I (Mar. 2015), pp. 76-82 
1-Maliki, Mohammed and Juan, Wang; 'Leadership Styles and Job Performance: a Literature Review'; Journal of International Business Research and Marketing. Volume 3, Issue 3, 2018,

Bangun, Wilson.Manajemen Sumber Daya Manusia. Jakarta: Erlangga Erlangga, 2012 Basit, Abdul; Sebastian, Veronica \& Hassan, Zubair,' Impacy of Leadership Style on Employee Performance (A Case Study a Private Organization in Malaysia)', International Journal of Accounting $\mathcal{E}$ Business Management, Vol. 5 (No. 2) November 2017

Elqadri, Zaenal Mustafa; Priyono; Suci, Rahayu Puji \& Chandra, Teddy; Effect of Leadership Style, Motivation, and Giving Incentives on the Performance of Employees-PT. Kurnia Wijaya Various Industries', International Education Studies; Vol. 8, No. 10; 2015

Habeeb, Munirat Yusuf \& Ibrahim, Yusuf,' Effects of Leadership Style on Employee Performance in

Nigerian Universities', Global Journal of Management and Business Research: A Administration and Management. Volume 17 Issue 7 Version 1.0 Year 2017

Hughes, Richard L., Ginnett Robert C. and Curphy. Gordon J., Leadership: Enhancing the Lessons of Experience, Boston, McGraw-Hill Irwin, 5th Edition, 2006.

Ibojo, Bolanle Odundani and Asabi, Oludele Matthew, 'Compensation Management and Employee Performance in the Manufacturing Sector, A Case Study of A Reputable Organization in the Food and Beverage Industry'. International Journal of Managerial Studies and Research (IJMSR), Volume 2, Issue 9, October 2014

Iqbal, N., Anwar, S. and Haider N, 'Effect of Leadership Style on Employee Performance', Arabian Journal of Business and Management Review, 2015

Mangkunegara. Anwar Prabu, Evaluasi Kinerja SDM, Cetakan ketujuh, Bandung, Refika Aditama, 2014

NawoseIng' ollan. Daniel \& Rousel, Josse,' Influence of Leadership Styles on Employees' Performance: A Study of Turkana County, Kenya'. International Journal of Business and Social Science Volume 8 • Number $7 \bullet$ July 2017

Peretomode, Otaroghene,'Situational and Contingency Theories of Leadership: Are They The Same?' JOSR journal of Business and Management (JOSR- JBM), Volume 4, Issue 3, Sept-Oct 2012.

Priatna, Cepi, Perilaku Organisasi, Bandung, PT Remaja Rodakarya, 2015

Shafie Bizhan, Baghersalimi, Zaeid and Vahid, Barghi,'The Relationship between Leadership Style and Employee Performance (Case Study of Real Estate Registration Organization of Tehran Province)', Singaporean Journal of Business Economics, and Management Studies, Vol. 2. No. 5. 2013.

Shirzad Kebria, Baharak and Zanganeh, Fatemeh Shirzad Kebria, Baharak; Zanganeh, Fatemeh,'The Relationship Between Senior Managers Leadership Style of School Districts of Tehran and Spirit of Administrators in Girls State School', Journal of Management Research and Training, 2011.

Sujarweni, V Wiratna. SPSS untuk Penelitian. Yogyakarta: Pustaka Baru, 2014

Sugiyono. Metode Penelitian Kualitatif. Bandung: Alfabeta, 2017

Sutikno. Pemimpin dan Kepemimpin: Tips Praktis untuk Menjadi Pemimpin yang diidolakan. Lombok; Holistica, 2014. 
Uwiyeze, Huguette and Muryungi, Patrick,'Influence of Compensation Practices on Employee Performance of Tea Companies in Rwanda: A Case Study of Rwanda Mountain Tea', European Journal of Business and Social Science, Vol. 6. No. 06, September 2017, pp. 160-167.

Veliu, Liridon; Manxhari, Mimoza; Demiri, Vizar \& Jahaj, Liridon,'The Influence of Leadership Styles on Employee's Performance', Vadyba Journal of Management . 2017, № 2 (31) 